
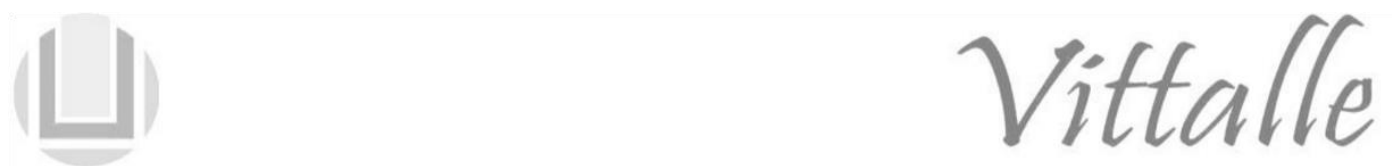

\title{
Anxiety and depressive behaviors in university students
}

\author{
Wildson Cardoso Assunção*
}

Universidade de Gurupi - UnirG, Gurupi, TO, Brasil

\section{Histórico do Artigo: \\ Recebido em: \\ 06/02/2020}

Aceito em:

$30 / 05 / 2020$

Keywords:

Anxiety; depression; university students; University

\section{Palavras-chave:}

Ansiedade;

depressão; estudantes

universitários;

Universidade

\begin{abstract}
The academic world represents challenges and dreams for many Brazilians. Factors such as anxiety and depression, however, can hinder the entry phase, the initial stages and even the completion of academic life. Several studies indicate that depression and anxiety are very common in the university population, suggesting more attention from the academic community and the need for psychological support. The objective of the study is to describe and raise aspects, signs and symptoms that trigger depressive behaviors and anxiety symptoms in university students. The present study is an integrative literature review, descriptive and with a qualitative approach. Publications from the last five years (2015-2019) were selected to cover more current content and discussions. Factors such as relationship difficulties, dissatisfaction with the course and insomnia were the main triggers of anxiety and depressive behaviors in university students. Aspects such as gender, age and socioeconomic situation directly influence the course of these symptoms. In conclusion, symptoms of anxiety and depressive behaviors are expressively frequent in university students, especially students in health courses. There is a lack of studies that seek to propose interventions and long-term monitoring. It is noticed that there is a need for strategies to assist and monitor the university population within the institutions.
\end{abstract}

Ansiedade e comportamentos depressivos em estudantes universitários

\section{RESUMO}

O mundo acadêmico representa desafios e sonhos para muitos brasileiros. Fatores como ansiedade e depressão, no entanto, podem prejudicar a fase de ingresso, as etapas iniciais e até mesmo a conclusão da vida acadêmica. Diversos estudos apontam que depressão e ansiedade são muito frequentes na população universitária, sugerindo mais atenção da comunidade acadêmica e necessidade de apoio psicológico. O objetivo do estudo é descrever e levantar aspectos, sinais e sintomas que desencadeiam comportamentos depressivos e sintomas de ansiedade em estudantes universitários. O presente estudo é uma revisão integrativa da literatura, descritiva e com abordagem qualitativa. Foram selecionadas publicações dos últimos cinco anos (2015-2019) para abranger conteúdos e discussões mais atuais. Fatores como dificuldade de relacionamentos, insatisfação com o curso e insônia apresentaram-se como desencadeadores principais de ansiedade e comportamentos depressivos em estudantes universitários. Aspectos como gênero, idade e situação socioeconômica influenciam diretamente no curso desses sintomas. Em conclusão, sintomas de ansiedade e comportamentos depressivos são expressivamente frequentes em estudantes universitários, especialmente os estudantes de cursos da saúde. Há carência de estudos que busquem propor intervenções e acompanhamento em longo prazo. Percebe-se que há necessidade de estratégias para atendimento e acompanhamento da população universitária dentro das instituições.

\section{Introduction}

Entering higher education represents dreams and challenges for many people. At the same time that there are new ways of accessing universities, such as social inclusion programs, distance learning, etc. there is more search for information about how professionals work, their remuneration and the possibilities of acting are some of the factors most considered by future academics. Adverse factors, such as the emergence of exacerbated reactions of anxiety in the face of everyday situations, generate deficit

\footnotetext{
* Corresponding author: wildson.se @ outlook.com (Assunção W.C.)
} 
behaviors that negatively affect and may even prevent a student from starting or continuing his journey. The most intense preparation for the university usually occurs during high school, a period marked by several biopsychosocial changes, expectations, uncertainties and, often, indecision about which profession to choose (1).

Much of this uncertainty is caused by socioeconomic factors and stability / instability in the labor market. Recent research shows that undecided students with the choice of course or area of activity are about four times more likely to develop stress or depressive behaviors. Associated to this, there can be even more disturbances in the family and social environment (2).

Natural changes in the transition period between adolescence and adult responsibilities are variables that have a major impact on the academic entry phase. If the experiences of this period are associated with social pressure, indecision and yearning, in addition to stress, there are more possibilities for the appearance of anxiety symptoms (3). While some studies show that the prevalence of depression and anxiety in students in the health area is higher than in students from other courses, others show results of depression and anxiety very close in this population compared to others (2).

In the university population, a study showed a prevalence of $30.6 \%$ of depression in students and only $9 \%$ in a non-university population (4). Other studies indicate that, in general, women would tend to have higher rates of depressive behaviors than men with the same age group. In Brazil, the most accessible support networks for university students are found in universities that offer a psychology course, through a Psychological Services Training Center. However, not all universities offer this course and when they offer it is common to experience overload of attendance (5) or insufficient number of interns who handle or meet the demand.

Despite this, the accessibility and ease of seeking care within the university may not be as applicable. A study carried out in a Psychological Services Training Center in the interior of the state of São Paulo/BR showed that there is a worrying dropout rate by university students who seek these services (5). This study considers that the psychotherapy process itself can demand a time that often discourages the patient, who expects faster results.

The therapeutic process itself in cases of anxiety or depression is more delicate, because during treatment, it is necessary to have reflections and changes in behavior that at first may seem difficult. In many cases, Cognitive-Behavioral Therapy - CBT (6) has been recognized and indicated for its effectiveness in cases of depression and anxiety. CBT has a direct and objective approach, which allows greater focus on current demands, in addition to providing active methods to the patient.

It is important to note that there are differences between anxiety symptoms and anxiety disorders. Symptoms are understood as signs or indicators of some abnormality (7).

Anxiety symptoms can be understood as deficient changes in the body such as irregular breathing, fear, tremors, dry mouth, and so forth (8). Anxiety disorders, on the other hand, are commonly defined as disorders of regular duration that cause these same symptoms linked to significant clinical impairment.

The literature shows that although there are differences in the manifestation of symptoms of anxiety and depression, there is a relationship between both (9), research that addresses these issues draws parallels between these two aspects. As in anxiety, depression can manifest itself through symptoms, behavioral, cognitive or as psychopathologies. Depressive behaviors in university or pre-university students are the most common social isolation, low self-esteem, depressive thoughts, irritable mood, among others (10).

The mental health of this population has become the focus of health professionals due 
to high rates and reports of emotional suffering and the consequent social impact (2). Competition for certain courses is challenging and requires even more emotional effort in an already stressful time. Often, the phase of attempting to enter university can be understood as a type of "rite of passage" between adolescence and autonomous adult life, considering several cultural and social implications (3).

Based on these reflections, the following question was reached: "What does the literature say about factors that trigger depressive behaviors and anxiety symptoms in university students?" Through the foregoing, the present study aimed to describe and raise aspects, signs and symptoms that trigger depressive behaviors and anxiety symptoms in university students.

\section{Methods}

The present study is an integrative literature review, descriptive and with a qualitative approach. This methodology is appropriate to provide a synthesis of knowledge through pre-established steps that generate practical results (11).

Data analysis takes place through a qualitative description, which allows a better understanding of the topics presented, in a more objective and succinct way. The search period was limited to the last five years (2015-2019) to cover more current content and discussions.

The search was made in Portuguese and English, using the descriptors: Anxiety, Depression, University Students, University. Researches with a descriptive and/or qualitative approach were prioritized. The databases used were the Virtual Health Library - VHL, including its indexed platforms, Researchgate, Google Scholar and publications of repositories and conference proceedings that brought relevant content to the research.

The inclusion criteria adopted for the selection of articles were: Publications published between 2015 and 2019; Published in Portuguese or English; It would need to be complete; It would need to cover the themes: depression, anxiety related to the academic population.

Incomplete articles were excluded; Paid; That were not hosted on official platforms; and that they did not describe was related to depressive behaviors and anxiety. Regarding anxiety symptoms and depressive behaviors, the following analyzes were considered: definition of symptoms; genre; age; and prevalence.

\section{Depression and anxiety in university students}

The fifth version of the DSM classifies depressive disorders and anxiety disorders according to the manifestation of their clinical symptoms, considering variables and correlations with aspects such as medical condition, use and abuse of psychoactive or pharmacological substances (12-14).

Adverse factors such as can modify the course of symptoms, such as use or abuse of psychoactive substance have a significant impact on anxiety symptoms and the triggering of depressive behaviors. The levels of anxiety, depression and stress in users of some types of drugs proved to be significant, especially in people who use tobacco (15).

Researchers conducted a study in Turkey that showed that as depression levels increase, anxiety levels also increase and also as depression levels decrease, anxiety levels decrease (13). The authors of this study considered that there are moderating variables that can modify the situation, depending on the type of anxiety and the type of depression manifested by the person.

Another recent study carried out with students in Iran showed worrying rates of 
symptoms of anxiety (not necessarily disorders) and depression, especially among young people over 18, the age in which in Brazil, it is marked by academic choices (16).

In the context of universities, there was a study that sought to study the symptoms of depression and anxiety in students of a private institution in the interior of Rio Grande do Sul/BR, which concluded that the rates raised were relatively close to those described in the literature and that, in addition, there was a considerable degree of other types of psychological distress (17).

This data reflects that in addition to symptoms of depression and anxiety, there are other worrying factors of suffering that need care and evaluation. In another study, it is possible to observe an analysis of the occurrence of symptoms such as dysphoria and other cases suggestive of depression (18).

It is possible to notice in the literature that different types of research establish symptomatic, physiological and cultural relationships that are more favorable to symptoms of depression and anxiety in an academic population, however, the effort to cope still seems weakened or unavailable.

Studies show that the appearance of symptoms of anxiety or depression in adolescents and young adults are factors that are frequently reported as compromising the admission to the academic world or their permanence in it $(16,19,20)$.

In some studies that deepen investigations of anxiety symptoms in university students, a considerable degree of problems with food was found, where anxiety maintains inappropriate eating behaviors to the appearance of eating disorders (12). More serious symptoms of eating disorders affect the individual's perception of himself, there may be an overvaluation of the shape and weight and quantity of food, and there are also situations where the person starts to eat non-nutritive substances (21).

Few studies have disclosed a relationship between anxiety levels and quality of life in the most diverse degrees $(22,23)$. A study with 649 university students highlighted that $103(75.8 \%)$ had a mild level of depression, $32(23.5 \%)$ had a moderate level and $1(0.7 \%)$ presented it severely. In this study, anxiety prevailed more frequently in women (2).

Organic factors determine much of the predisposition for the emergence of depression and anxiety, subjective factors determine how a person will react to these new situations.

The academic environment requires new attitudes and skills from students that may imply an increase in the occurrence of mental health problems. Depression is one of the diseases that most commonly affect students (24).

\section{Results and discussion}

The bibliographic survey resulted in 65 results using the combined descriptors "anxiety; depression; University students; university". The search for these same separate descriptors generated different and misaligned results with the main objective. After that, each of the abstracts was read, in order to filter the publications, in search of the most relevant ones that favored the desired discussion.

After reading the abstracts and selecting the publications, a total of 31 studies were selected that made up the body of the work. The other surveys were disregarded for not meeting the inclusion/exclusion criteria or for not being directly related to the main objective.

Several studies were found that related anxiety and depression in the university population $(10,17,18,20)$, which discussed based on a comparison between academic and non-academic population, considering course, age, gender and income. These studies described risk factors and factors that favored isolation and depression.

The proportion of Brazilian surveys in the sample was equivalent to surveys conducted 
in other countries. Research with large samples showed equivalent and proportional results to research with smaller samples. Research with an emphasis on treatment or intervention appeared less frequently when compared to research aimed at identifying and describing functional and dysfunctional aspects of anxiety and depression.

Results for signs and symptoms of anxiety and anxiety disorders were related, however, were not conclusive as to the difference between both. Depressive behavior and depression were shown to be related in research, especially in classifications that involved symptoms of depressed mood (25).

From the theoretical reflections, it can be seen that despite the high indexes of depression and being also one of the biggest public health problems (6) people can manifest depressive behaviors, which can be categorized as less intense and of shorter duration.

Few authors were found who used the expression "depressive behavior". A study, however, emphasized the importance of psychological interventions in socioemotional disorders, including depressive behaviors (6). Another study mentioned "depressive behaviors" to refer also to genetic factors present in depression (27).

Most of the authors, and according to their studies, were concerned with describing factors of anxiety and depression and classifying them according to the results presented by the participants of their research. To demonstrate the nature and symptoms of assessed behaviors related to anxiety and depression in college, a list in Table 1 was carried out just below that reflects and displays the data on symptoms of depression and anxiety and instruments used by some of the authors discussed.

Table 1 - Factors of anxiety, depression and assessment instruments in university students.

\begin{tabular}{|c|c|c|c|}
\hline Authors & Anxiety Factors & Depression Factors & Assessment Tools \\
\hline Cardozo et al. (1) & $\begin{array}{l}\text { Insecurity; Fear; excess } \\
\text { of curricular activities; } \\
\text { Teaching methodology; } \\
\text { Difficulty in managing } \\
\text { time to deliver activities. }\end{array}$ & $\begin{array}{l}\text { Classifies it as a } \\
\text { secondary factor, and } \\
\text { may appear after } \\
\text { successive repetitions of } \\
\text { anxiety factors. }\end{array}$ & $\begin{array}{l}\text { Hamilton Anxiety } \\
\text { Assessment Scale; } \\
\text { Own semi-structured } \\
\text { questionnaire. }\end{array}$ \\
\hline Leão et al. (2) & $\begin{array}{l}\text { Bad or insufficient } \\
\text { interpersonal } \\
\text { relationship; Insomnia; } \\
\text { Lack of physical } \\
\text { activities; Concern for } \\
\text { the future. }\end{array}$ & $\begin{array}{l}\text { Dissatisfaction with the } \\
\text { course; Dynamics of } \\
\text { family relationships; } \\
\text { Sleep Quality; Social } \\
\text { relationship. }\end{array}$ & $\begin{array}{l}\text { Own questionnaire; Beck } \\
\text { Depression Inventory } \\
\text { (BDI); Beck Anxiety } \\
\text { Inventory (BAI). }\end{array}$ \\
\hline Fernandes et al. (4) & $\begin{array}{l}\text { Nervousness; Feeling of } \\
\text { being scared; } \\
\text { Indigestion or } \\
\text { abdominal discomfort. }\end{array}$ & $\begin{array}{lr}\text { Fatigue; } & \text { Irritability; } \\
\text { Somatic concerns; Sleep } \\
\text { disorders; } \\
\text { indecision. }\end{array}$ & $\begin{array}{l}\text { Sociodemographic and } \\
\text { Occupational } \\
\text { Questionnaire; Beck } \\
\text { Anxiety Inventory (BAI); } \\
\text { Beck Depression } \\
\text { Inventory (BDI). }\end{array}$ \\
\hline
\end{tabular}

Table 1 reflects some of the factors and instruments that each author used and identified in his studies. It is important to note that each of these authors are professionals from different areas, and there may be discrepancies in their conceptual definitions and methodologies.

On the other hand, the instruments used in most research were of similar categories that favor more approximate results between studies. It is worth mentioning the use especially the BAI and BDI scales, which are currently unfavorable by the Psychological Test Assessment System - SATEPSI (28) since April 2018.

From Table 1, we can associate some factors of anxiety and depression as favorable to 
the worsening of psychiatric conditions and clinical symptoms, in case of non-treatment. Thus, Table 2 below sought to demonstrate how these clinical symptoms could evolve according to the symptoms presented in DSM-V (29).

Table 2 - Possible course of symptoms.

\begin{tabular}{lll}
\hline Symptoms & Risk factors & Prognosis \\
\hline Difficulties in time management; & Temperamental; & Anxiety disorders; Depressive \\
Excessive concern about the future; & environmental issues; disorders; & \\
Nervousness; Bad eating habits. & genetic and physiological. & Eating disorders. \\
Insomnia; Sleep disorders; Bad & $\begin{array}{l}\text { Temperamental; } \\
\text { dynamics of interpersonal }\end{array}$ & $\begin{array}{l}\text { Sleep-wake disorders; Depressive } \\
\text { genetic and physiological; }\end{array}$ \\
relationships. & $\begin{array}{l}\text { course modifiers. } \\
\text { Temperamental; } \\
\text { Insecurity; Fear; Discomfort. }\end{array}$ & Panic attacks; Panic disorder. \\
& & \\
\hline
\end{tabular}

The possibilities presented in Table 2 depend, however, on several other possible variables, such as use and/or abuse of psychoactive substances, predisposition, exposure, inadequate treatment and non-treatment. The prevalence of anxiety and depression is higher in females ${ }^{2}$. The prevalence in relation to age is more complex, since, in Brazil, not all students access universities at the same age or under the same conditions. However, it is possible to define a sample from the results obtained, which evaluated mostly people between 17 and 24 years old.

Currently, there are projects with new teaching configurations, where the elderly gain space and new possibilities through universities focused on the Elderly (30). In recent research it is possible to observe that these universities provide more quality of life for this population, reducing dramatically aggravating factors such as depression and anxiety (31).

In relation to the chosen course, the bibliographic survey showed that students taking a course in the health field $(1,2,10,16,20)$ were more likely to have symptoms of anxiety and depressive behaviors. As for the nature of the students' institution, it was not possible to establish a direct relationship.

Regarding the academic period, there were discrepancies, while some authors indicate that pre-university entrance exams or Brazilian's National High School Examination ENEM, in conjunction with the end of adolescence, other authors mention symptoms of depression and anxiety in the early years of the course, where there are yearnings, uncertainties and often dropouts due to non-adaptation.

Much of this research has not attempted to establish a parallel between the development of symptoms or considered possible course modifiers. Professionals from different areas have obtained similar results in their research, especially in the items surveyed, such as definition of symptoms, gender, age, and prevalence of symptoms.

\section{Conclusion}

Symptoms of anxiety and depressive behaviors are expressively frequent in university students, especially students in health courses. Little research has attempted to describe or discuss isolated depressive or anxiety behaviors, although there are clear differences, which involve intensity, duration and frequency.

It is important to note that not all published results represent the real situation of the evaluated participants. Factors such as anxiety and depression may have a limited duration in some cases and may be subject to a distorted perception of the individual. 
None of the surveys surveyed presented cross-sectional methodologies or proposed to seek the diagnosis of doctors or psychologists who evaluated and collected data that really the university students evaluated were subject to some anxiety or depression disorder. Thus, we can understand that symptoms - isolated - are more frequent in this population than syndromes or disorders.

However, the research used instruments recognized worldwide, such as BAI and BDI, which provided approximate results in each of the samples surveyed, which suggests that all students, university students or not, are subject to symptoms of anxiety and depression at some stage of academic life.

There is a need for strategies to assist and monitor the university population, considering that not all academics seek this monitoring, either due to the difficulty or inexistence of finding these services or due to fear and resistance to accept a psychotherapeutic process.

Depression is a potentially serious disease, predicted to become one of the biggest problems in public health worldwide in 2020. Therefore, to the same extent, aspects of anxiety can damage the quality of learning of future professionals, in addition to other losses that can develop in case there are no actions to assist this problem.

It is noteworthy that the proposed review method did not allow conclusive discussions about the correlation of the themes exposed, especially in a population as varied in modality, gender and age as university students.

This research made use of a small cut in the literature, due to this, the results presented are partial. It is necessary to carry out empirical and cross-sectional research, which allows the assessment of symptoms, course and aspects that can describe and conclude whether university students are subject only to more serious symptoms or diseases.

In addition, there is also a need for studies that seek to propose interventions. The monitoring of this population is also necessary for the training with excellence of these future professionals, since in this way it is possible to graduate professionals who know their own limitations and who have developed their emotional integrity. Higher education institutions have a key role to play in promoting these possibilities.

\section{References}

1. Cardozo MQ, Gomes KM, Fan LG, Soratto MT. Fatores associados à ocorrência de ansiedade dos acadêmicos de Biomedicina. Saúde e Pesquisa, Maringá/PR 2016; 9 (2): 251-262.

2. Leão AM, Gomes IP, Ferreira MJM, Cavalcanti LPG. Prevalência e Fatores Associados à Depressão e Ansiedade entre Estudantes Universitários da Área da Saúde de um Grande Centro Urbano do Nordeste do Brasil. Revista Brasileira de Educação Médica 2018; 42(4): 55-65.

3. Daolio CC, Neufeld CB. Intervenção para stress e ansiedade em pré-vestibulandos: estudo piloto. Revista Brasileira de Orientação Profissional 2017; 18(2): 129-140.

4. Fernandes MA, Vieira FER, Silva JS, Avelino FVSD, Santos JDM. Prevalência de sintomas ansiosos e depressivos em universitários de uma instituição pública. Rev Bras Enferm 2018; 71(suppl 5): 2298304, 2018.

5. Cerioni RAN, Herzberg E. Expectativas de Pacientes acerca do Atendimento Psicológico em um Serviço-Escola: da Escuta à Adesão. Psicologia: Ciência e Profissão 2016; 36(3): 597-609.

6. Assunção WC, Silva JBF. Aplicabilidade das técnicas da terapia cognitivo-comportamental no tratamento de depressão e ansiedade. Educação, Psicologia e Interfaces 2019; 3(1): 77-94.

7. Carneiro AV. Sintomas e sinais: uma abordagem científica do exame clínico. Rev Port Med Geral Fam $2017 ; 33: 10-13$

8. Obelar RM. Avaliação psicológica nos transtornos de ansiedade: estudos brasileiros. Universidade Federal do Rio Grande do Sul. (Monografia) Especialização em Avaliação Psicológica, 2016.

9. Assunção WC, Silva JBF. Depressão e Suicídio sob a Perspectiva da Psicologia CognitivoComportamental. Revista Saúde em Foco, Teresina 2019; 6(1): 85-102. 
10. Nogueira MJC. Saúde mental em estudantes do ensino superior: fatores protetores e fatores de vulnerabilidade. Universidade de Lisboa. (Tese) Doutorado em enfermagem, 2017.

11. Sousa L, Marques-Vieira C, Severino S, Antunes V. Metodologia de Revisão Integrativa da Literatura em Enfermagem. Revista Investigação Enfermagem 2017; 2: 17-26.

12. A \& C Black Publishers Ltd. Dictionary of Medical Terms. Text Production and Proofreading Heather Bateman, Ruth Hillmore, Daisy Jackson, Sarah Lusznat, Katy McAdam, Charlotte Regan. ISBN-13: 978-1-4081-0209-1. Graphycems, 2007.

13. Karadağ E, Sölpük N. Relationship Between Depression and Anxiety Symptoms: A Meta-analysis Study. Dusunen Adam: The Journal of Psychiatry and Neurological Sciences; 2018.

14. Maina G, Mauri M, Rossi A. Anxiety and depression. Journal of Psychopathology 2016; 22: 236-250.

15. Andretta I, Limberger J, Schneider JA, Mello LTN. Sintomas de Depressão, Ansiedade e Estresse em Usuários de Drogas em Tratamento em Comunidades Terapêuticas. Psico-USF, Bragança Paulista 2018; 23(2): 361-373.

16. Khesht-Masjedi M, Shokrgozar S, Abdollahi E, Habibi B, Asghari T, Ofoghi RS, Pazhooman S. The relationship between gender, age, anxiety, depression, and academic achievement among teenagers. Journal of Family Medicine and Primary Care 2019; 8(3): 799.

17. Bardagi M, Brandtner M. Sintomatologia de Depressão e Ansiedade em Estudantes de uma Universidade Privada do Rio Grande do Sul. Gerais: Revista Interinstitucional de Psicologia 2009; 2(2), $81-91$.

18. Grazziano ES, Bianchini C, Lopes LFD, Souza BF, Franco DM. Resistência ao estresse e depressão em estudantes de cursos técnicos em enfermagem. Rev enferm UFPE on line., Recife 2015; 9(supl. 2): 837-43.

19. Barroso NAF, Rocha MES, Holanda, RA, Feijão GMM. Avaliação do nível de estresse em prévestibulandos. ANAIS do IX Encontro de Pesquisa e Extensão da Faculdade Luciano Feijão 2017; 1-11.

20. Barros RFO. Ansiedade e depressão em universitários estudantes de Educação Física da Universidade Federal de Santa Catarina. (TCC) Educação Física - Universidade Federal de Santa Catarina, 2017.

21. Schmidt U, Adan R, Bohm I, Campbell IC, Dingemans A, Ehrlich S, et al. Eating disorders: The big issue. The Lancet Psychiatry 2016; 3(4): 313-315.

22. Agarwal A. Pica- An Enigma of Malnutrition. J Nutr Disorders Ther 2017; 7:2

23. Lantyer AS, Varanda CC, Souza FG, Padovani RC, Viana MB. Ansiedade e Qualidade de Vida entre Estudantes Universitários Ingressantes: Avaliação e Intervenção. Revista Brasileira de Terapia Comportamental e Cognitiva 2016; 8 (2): 4-19.

24. Brondani MA, Hollerbach MD, Rodrigues EP, Silva GP, Corrêa A. O transtorno depressivo entre estudantes universitários. IV Mostra Integrada de Ensino, Pesquisa e Extensão da Fisma 2018; 1-13.

25. TeleCondutas. Depressão. Org. por Milena Rodrigues Agostinho \& Natan Katz. Universidade Federal do Rio Grande do Sul, 2017.

26. Bembnowska M, Jośko-Ochojska, J. What causes depression in adults? Pol J Public Health 2015; 125(2): 116-120.

27. Kim CS, Brager DH, Johnston D. Perisomatic changes in h-channels regulate depressive behaviors following chronic unpredictable stress. Molecular Psychiatry 2018; 23: 892-903.

28. Conselho Federal de Psicologia. Sistema de Avaliação de Testes Psicológicos (SATEPSI). Disponível em: http//satepsi.cfp.org.br.

29. American Psychiatric Association. Manual diagnóstico e estatístico de transtornos mentais: DSM-5. 5. ed. Porto Alegre: Artmed, 2014.

30. De Souza IM, Da Rocha RA. Universidade Da Terceira Idade, Compromisso Social e Compromisso Institucional. Extensio: R. Eletr. de Extensão 2017; 14(27): 4-18.

31. Inouye K, Orlandi FS, Pavarini, SCL, Pedrazzani ES. Efeito da Universidade Aberta à Terceira Idade sobre a qualidade de vida do idoso. Educação e Pesquisa 2017; 44: e142931. 